\title{
Observations on the evolving fields of neuroimmunology and neuroinflammation
}

\section{OPEN}

Correspondence to Dr. Dalmau:

Jdalmau@clinic.ub.es

Neurol Neuroimmunol Neuroinflamm

2015;2:e67; doi: 10.1212/ NXI.0000000000000067
In this fifth issue of Neurology ${ }^{\circledR}$ Neuroimmunology \& Neuroinflammation (N2), I want to start by thanking Drs. Richard Ransohoff and Robert Gross and the staff of N2 and Neurology for giving me the opportunity to serve as Editor. I initially hesitated, as I could not see myself matching what Richard, with his extraordinary editorial, scientific, and clinical expertise, had accomplished in the short time since N2 was launched. Persuasive and reassuring words from Richard and Bob, along with the immediate support of the extraordinary N2 team, convinced me that this was a unique opportunity. Since the first day, my task has been facilitated by the unconditional help of Dr. Scott Zamvil, current Deputy Editor of N2.

Extraordinary advances in the fields of neuroimmunology and neuroinflammation, including the discovery of new antibody-associated diseases of both central and peripheral nervous systems and the development of a new subspecialty, "autoimmunity neurology," among others, are fueling excitement and attracting increasing numbers of clinical and basic investigators to these disciplines. It is common to meet neurology residents and young investigators asking how and where they can be trained or carry out research in these fields. The American Academy of Neurology and other neurological associations in the United States and abroad are dedicating courses and scientific sessions at their annual meetings to adapt to this rapidly developing subspecialty. The identification of new disorders and an exponentially increasing body of work in multiple sclerosis (MS) and related diseases called for a dedicated journal and was the basis for the development of $\mathrm{N} 2$.

The launching of N2 and its relationship to the journal Neurology have raised some questions that I would like to address in this (my first) "Editor's Corner." The mission of N2 is to provide peer-reviewed articles, editorials, and reviews focused on neuroinflammation and neuroimmunology to enhance patient care, education, and clinical and translational research. There are 2 ways that articles arrive at the N2 editorial offices. First, and increasing in number, are manuscripts that are directly submitted to N2. Second are manuscripts that are submitted to Neurology but redirected to $\mathrm{N} 2$ at the suggestion of the editors. This may occur without review because the topic clearly relates to the mission of $\mathrm{N} 2$, or after review when publication is not possible due to space limitations or the theme of the article is deemed more appropriate for N2. Once received at the N2 offices, all manuscripts are assessed by the editor or associate editors. If previously reviewed by Neurology, those reviews and authors' responses are considered and additional reviews may be obtained before a decision is made. All accepted manuscripts are currently included in PubMed, and due to the "open access" format, the content of $\mathrm{N} 2$ can be accessed free. This allows for rapid dissemination of information among clinicians and researchers.

A brief review of some of the studies in this fifth issue of $\mathrm{N} 2$ shows the diversity of topics within the scope of the journal. While I found all the articles to be informative and interesting, due to space constraints I will only mention a few. Dr. Hacohen et al. ${ }^{1}$ report 8 infants born to mothers with symptomatic myasthenia gravis or mothers who were asymptomatic but had elevated acetylcholine receptor (AChR) antibodies. The study suggests that myopathic features after transient neonatal myasthenia gravis may be more common than expected and that fetal AChR inactivation syndrome should be considered in infants with unexplained myopathic features, particularly dysarthria and velopharyngeal incompetence. Dr. Thames et al. ${ }^{2}$ examined individuals with hepatitis $\mathrm{C}$ virus (HCV) infection using comprehensive neurocognitive assessments and high-resolution brain MRI, diffusion tensor imaging, and magnetic resonance spectroscopy. Their findings indicate that $\mathrm{HCV}$-associated neurologic complications disrupt frontostriatal structures, likely resulting in fatigue and poor cognitive performance in domains regulated by frontostriatal regions. Serre-Miranda et al. ${ }^{3}$ report that lower numbers of peripheral blood effector memory $\mathrm{CD}^{+} \mathrm{T}$ cells and higher numbers of naïve $\mathrm{CD} 8^{+}$

From the Catalan Institution of Research and Advanced Studies (ICREA) and Biomedical Research Institute August Pi i Sunyer (IDIBAPS), Hospital Clinic, University of Barcelona, Barcelona, Spain.

Go to Neurology.org/nn for full disclosures. Funding information and disclosures deemed relevant by the author, if any, are provided at the end of the editorial.

This is an open access article distributed under the terms of the Creative Commons Attribution-Noncommercial No Derivative 3.0 License, which permits downloading and sharing the work provided it is properly cited. The work cannot be changed in any way or used commercially. 
$\mathrm{T}$ cells and $\mathrm{B}$ cells are associated with better cognitive performance in healthy aging; moreover, the effector memory $\mathrm{CD}_{4}{ }^{+} \mathrm{T}$ cells were found to be predictors of general and executive function and memory. Dr. Perumal et al. ${ }^{4}$ report that 6 out of 17 (43\%) patients with neuromyelitis optica (NMO) treated with rituximab (RTX) experienced a clinical exacerbation within 1 week of the first infusion. This experience and review of the literature led these authors to postulate that a RTX-induced surge of proinflammatory cytokines (tumor necrosis factor $\alpha$, interleukin 6 , B-cell activating factor) and pathogenic aquaporin-4 (AQP4) antibodies in addition to an incompletely repaired blood-brain barrier are likely responsible for the disease exacerbation. This would explain why the symptom exacerbation usually involves the same anatomic region that was affected by pre-RTX induction flares. Drs. Zamvil and Slavin ${ }^{5}$ provide a stimulating Views \& Reviews article discussing the clinical significance and implications of myelin oligodendrocyte glycoprotein (MOG) antibody-associated NMO-like symptoms. They argue that in contrast to classical $\mathrm{NMO}$, which occurs with AQP4 antibodies (defining the disease as an astrocytopathy), the syndromes related to MOG antibodies represent oligodendrogliopathies. These authors raise the intriguing question of whether NMO spectrum disorder-like phenotype associated with MOG antibodies represents a variant of opticospinal MS. In an equally inspiring editorial comment, Drs. Reindl and Rostasy ${ }^{6}$ remind us of the spectrum of MOG antibody syndrome associations in the pediatric population and suggest collectively naming these disorders "MOG antibody-associated diseases" to reflect their much broader clinical spectrum compared with that seen in AQP4 antibody-associated NMO spectrum disease. Because the clinical manifestations associated with MOG antibodies are often monosymptomatic, the immunologic characterization has practical consequences, as many of these patients may not need immunosuppression or immunomodulation after recovery.
These are just a few of the excellent articles that can be found in N2, and they demonstrate the breadth and wealth of information available. I encourage you to browse the journal and submit your work. We want N2 to be your forum to raise the questions for future research and provide answers that will advance our field and improve the lives of our patients. I look forward to working with all of the authors and researchers in the months to come.

\section{DISCLOSURE}

J. Dalmau is the editor of Neurology: Neuroimmunology \& Neuroinflammation; is on the editorial board for Neurology UpToDate; holds patents for and receives royalties from Ma2 autoantibody test and NMDA receptor autoantibody test, and has patent applications for and receives royalties from $\mathrm{GABA}(\mathrm{B})$ receptor autoantibody test, $\mathrm{GABA}(\mathrm{A})$ receptor autoantibody test, DPPX autoantibody test, and IgLON5 autoantibody test; and received research support from Euroimmun, NIH, and Fondo de Investigaciones Sanitarias de la Seguridad Social (Instituto Carlos III, Spanish Government). Go to Neurology.org/nn for full disclosures.

\section{REFERENCES}

1. Hacohen Y, Jacobson LW, Byrne S, et al. Fetal acetylcholine receptor inactivation syndrome: a myopathy due to maternal antibodies. Neurol Neuroimmunol Neuroinflamm 2015;2: e57. doi: 10.1212/NXI.0000000000000057.

2. Thames AD, Castellon SA, Singer E, et al. Neuroimaging abnormalities, neurocognitive function, and fatigue in patients with hepatitis C. Neurol Neuroimmunol Neuroinflamm 2015;2:e59. doi: 10.1212/NXI.0000000000000059.

3. Serre-Miranda C, Roque S, Correia Santos N, et al. Effector memory CD4 $+\mathrm{T}$ cells are associated with cognitive performance in a senior population. Neurol Neurimmunol Neuroinflamm 2015;2:e54. doi: 10.1212/NXI.0000000000000054.

4. Perumal JS, Kister I, Howard J, Herbert J. Disease exacerbation after rituximab induction in neuromyelitis optica. Neurol Neuroimmunol Neuroinflamm 2015;2:e61. doi: 10.1212/NXI.0000000000000061.

5. Zamvil SS, Slavin AJ. Does MOG Ig-positive AQP4seronegative opticospinal inflammatory disease justify a diagnosis of NMO spectrum disorder? Neurol Neuroimmunol Neuroinflamm 2015;2:e62. doi: 10.1212/ NXI.0000000000000062.

6. Reindl M, Rostasy K. MOG antibody-associated diseases. Neurol Neuroimmunol Neuroinflamm 2015;2:e60. doi: 10.1212/NXI.0000000000000060. 


\title{
Neurology \\ Neuroimmunology \& Neuroinflammation
}

\author{
Observations on the evolving fields of neuroimmunology and neuroinflammation \\ Josep Dalmau \\ Neurol Neuroimmunol Neuroinflamm 2015;2; \\ DOI 10.1212/NXI.0000000000000067
}

This information is current as of February 5, 2015

Updated Information \&

Services

References

Permissions \& Licensing

Reprints including high resolution figures, can be found at:

http://nn.neurology.org/content/2/1/e67.full.html

This article cites 6 articles, 0 of which you can access for free at: http://nn.neurology.org/content/2/1/e67.full.html\#\#ref-list-1

Information about reproducing this article in parts (figures,tables) or in its entirety can be found online at:

http://nn.neurology.org/misc/about.xhtml\#permissions

Information about ordering reprints can be found online:

http://nn.neurology.org/misc/addir.xhtml\#reprintsus

Neurol Neuroimmunol Neuroinflamm is an official journal of the American Academy of Neurology.

Published since April 2014, it is an open-access, online-only, continuous publication journal. Copyright $\odot$ 2015 American Academy of Neurology. All rights reserved. Online ISSN: 2332-7812.

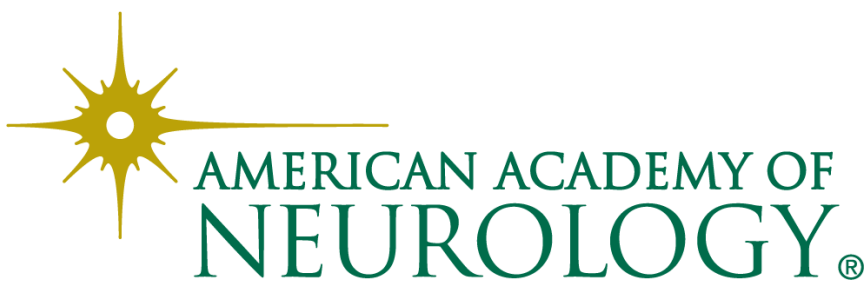

